\title{
OPTIMASI METODE LISIS ALKALI UNTUK MENINGKATKAN KONSENTRASI PLASMID
}

\section{Optimization of Alkaline Lysis Method for the Improvement of Plasmid Concentration}

\author{
Dudi Hardianto ${ }^{1, *}$, Alfik Indarto ${ }^{2}$, Nurtjahjo Dwi Sasongko ${ }^{2}$ \\ ${ }^{1}$ Balai Pengkajian Bioteknologi BPPT, Gedung 630 Kawasan PUSPIPTEK, Setu, \\ Tangerang Selatan, Banten 15314 \\ ${ }^{2}$ Fakultas Biologi, Universitas Jenderal Soedirman, Purwokerto, Jawa Tengah 53122 \\ *E-mail: dudi.hardianto@bppt.go.id
}

\begin{abstract}
Plasmids are extra chromosomal molecules of DNA that replicate autonomously and found in prokaryote and eukaryote cells. There are a number of methods that are used to isolate plasmids, such as alkaline lysis, boiling lysis, using cesium chloride, and chromatography. Amongst the disadvantages in plasmid isolation methods are lengthy time especially when handling a large number of samples, high cost, and low purity. Alkaline lysis is the most popular for plasmid isolation because of its simplicity, relatively low cost, and reproducibility. This method can be accomplished in 50 minutes to one hour. In this research, the alkaline lysis method was developed to obtain suitable plasmid for applications in a molecular biology laboratory. The aim of this research was to reduce contaminants and improve yield of plasmid. The result of isolation of pICZA plasmid in Escherichia coli gave the concentration of 3.3 to $3.8 \mu \mathrm{g} / \mu \mathrm{L}$ with the purity of 1.99 .
\end{abstract}

Keywords: Plasmid isolation, p/CZ A, Escherichia coli, rapid, alkaline lysis

\section{ABSTRAK}

Plasmid merupakan molekul DNA ekstrakromosomal yang bereplikasi secara mandiri dan ditemukan dalam sel prokariot dan eukariot. Banyak metode yang digunakan untuk isolasi plasmid, seperti: lisis alkali, lisis dengan pemanasan, penggunaan sesium klorida, dan kromatografi. Kelemahan beberapa metode isolasi DNA adalah waktu isolasi yang lama terutama saat isolasi plasmid dalam jumlah banyak, mahal dan kemurniannya yang rendah. Metode lisis alkali merupakan metode yang sangat umum untuk isolasi plasmid karena mudah dilakukan, relatif murah, dan reprodusibilitas. Metode ini dapat dilakukan dalam 50 menit sampai 1 jam. Pada penelitian ini dikembangkan metode lisis alkali untuk memperoleh plasmid yang sesuai untuk penggunaan di laboratorium biologi molekuler. Tujuan dari penelitian ini adalah untuk mengurangi jumlah kontaminan dan meningkatkan konsentrasi plasmid. Hasil isolasi plasmid pICZA dalam Escherichia coli mempunyai konsentrasi antara 3,3 sampai $3,8 \mu \mathrm{g} / \mu \mathrm{L}$ dan kemurniannya 1,99 .

Kata Kunci: Isolasi plasmid, pICZ A, Escherichia coli, cepat, lisis alkali 


\section{PENDAHULUAN}

Plasmid merupakan molekul DNA ekstrakromosomal yang dapat bereplikasi (memperbanyak diri) secara mandiri dan ditemukan dalam sel prokariot dan eukariot. Secara alami plasmid terdapat pada bakteri dan beberapa organisme eukariot seperti Saccharomyces ceriviseae. Ukuran plasmid bervariasi antara $1 \mathrm{~kb}$ sampai $200 \mathrm{~kb}$. Dalam penelitian rekayasa genetika, plasmid digunakan sebagai kendaraan molekuler untuk memasukkan gen dari luar ke dalam sel inang (Palomares et al. 2004; Yadav et al. 2011). Plasmid mempunyai 3 komponen penting yaitu: 1) Origin of replication (ORI), sehingga plasmid dapat bereplikasi secara mandiri, 2) mempunyai daerah unik sebagai situs pemotongan enzim endonuclease, yang biasa disebut multiple cloning site (MCS), 3) membawa penanda seleksi (biasanya resistensi terhadap antibiotika) untuk membedakan antara sel inang yang mengandung plasmid atau tidak.

Klasifikasi plasmid berdasarkan karakteristik gen yang dikodenya. Terdapat 5 jenis plasmid (Brown 2010), yaitu: 1) plasmid fertilitas atau $F$, membawa gen tra sehingga plasmid dapat berpindah secara konyugasi, contoh plasmid $\mathrm{F}$ pada $E$. coli, 2) plasmid resisten atau $R$, membawa gen resistensi terhadap antibiotika, contoh: resistensi terhadap kloramfenikol, ampisilin, dan zeocin, 3) Plasmid Col mempunyai gen pengkode protein kolisin, protein yang dapat membunuh bakteri lain, contoh ColE1 pada E. coli, 4) plasmid degradatif memungkinkan sel inang memetabolisme senyawa yang tidak umum (toluene dan asam salisilat), contoh: Tol pada Pseudomonas putida, 5) plasmid virulensi, memungkinkan sel inang dapat menginfeksi organisme lain. Contoh plasmid Ti pada Agrobacterium tumefaciens

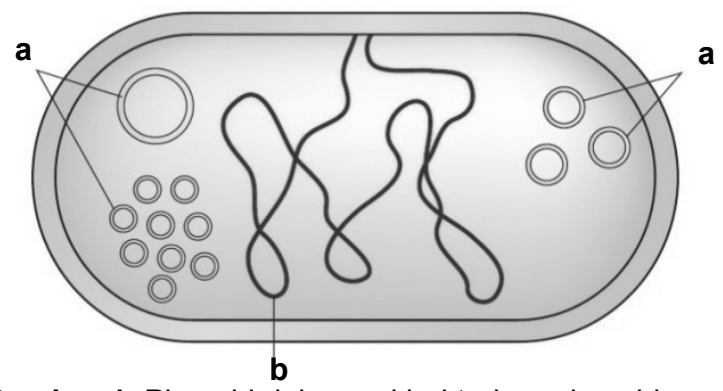

Gambar 1. Plasmid dalam sel bakteri, a: plasmid, b: kromosom bakteri (Brownj 2010) sehingga dapat menginfeksi tanaman dikotiledon. Plasmid pICZ A merupakan salah satu jenis plasmid resisten yang mempunyai gen pengkode resisten terhadap zeocin.

Plasmid yang pertama kali dikonstruksi adalah plasmid pBR322 (pada tahun 1974) dan merupakan salah satu plasmid yang pertama kali digunakan dalam rekayasa genetika. Sistem penamaan plasmid menggunakan huruf dan angka. Sebagai contoh pBR322, $p$ berarti pasmid, BR merupakan nama orang yang pertama kali mengkonstruksi plasmid (Bolivar dan Rodriquez), dan 322 merupakan nomor identitas spesifik dari plasmid (Balbas et al. 1986). Pada penelitian ini digunakan plasmid pICZ A sebagai model untuk optimasi isolasi plasmid dengan metode lisis alkali. Plasmid pICZ A berukuran 3329 bp mempunyai pUC sebagai ORI yang berasal dari Escherichia coli (E. coli) sehingga dapat bereplikasi di sel E. coli, mempunyai daerah MCS dengan 10 situs enzim restriksi, dan membawa penanda seleksi resitensi terhadap antibiotika zeocin (gen Sh ble). Perbedaan antara plasmid pICZ A, pICZ B, dan pICZ C adalah pada salah satu dari 10 situs enzim restriksi, untuk pICZ A terdapat Apa I, pICZ B Xba I, sedangkan pICZ C Snab I. Kelebihan plasmid pICZ A selain dapat bereplikasi dalam E. coli juga dapat terintegrasi ke dalam genom Pichia pastoris.

Sejak ditemukan plasmid, telah banyak metode dikembangkan untuk mengisolasi plasmid. Metode isolasi plasmid yang tepat sangat penting untuk mendapatkan plasmid dengan konsentrasi dan kemurnian yang tinggi. Keberhasilan Polymerase Chain Reaction (PCR), penentuan urutan DNA (sequencing), dan kloning gen sangat ditentukan oleh konsentrasi dan kemurnian plasmid. Beberapa metode isolasi plasmid antara lain: lisis alkali, lisis dengan pemanasan, menggunakan bahan kimia sesium klorida, metode dengan menggunakan microwave (Dederich et al. 2002), dan metode kromatograpi (Birnboim dan Doli 1979). Metode isolasi plasmid yang biasa dipakai adalah lisis alkali dan lisis dengan pemanasan (Kiran et al. 2010; Perez-ortin et al. 1986; Yadav et al. 2011). Kelemahan metode lisis dengan pemanasan adalah beberapa $E$. coli seperti HB101t 


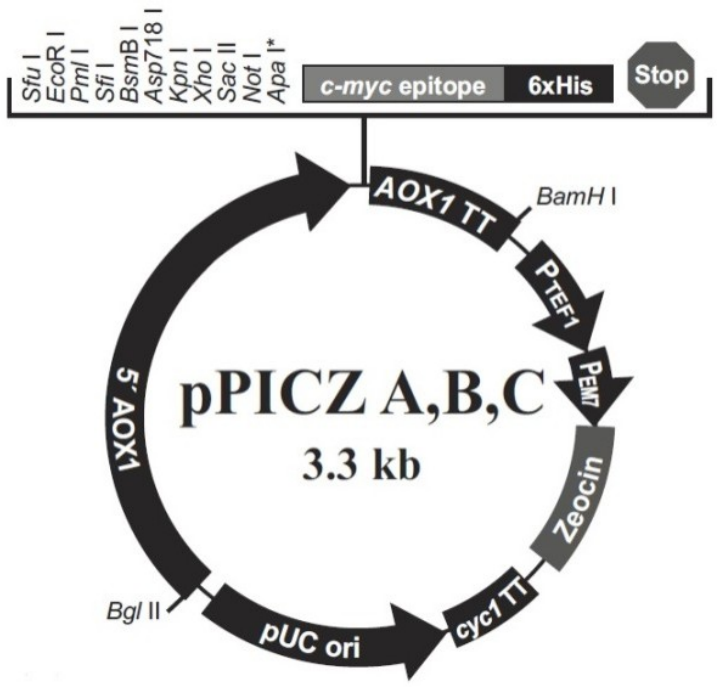

Gambar 2. Plasmid pICZ A (Easyselect Pichia Expression Kit 2015)

selnya tidak dapat dilisis dengan pemanasan (Sambrook dan Russell 2001). Metode lain untuk isolasi plasmid dengan menggunakan sesium klorida, yang sangat mahal, korosif, toksik, dan memerlukan waktu yang sangat lama, sehingga metode ini jarang digunakan (Perez-ortin et al. 1986). Banyak kit untuk isolasi plasmid beredar di pasaran. Kit ini menggunakan kolom kromatografi sekali pakai untuk mengabsorpsi plasmid. Matriks yang digunakan beragam, antara lain gelas, resin anion (dietilaminoetil, dietil-2hidroksipropil-aminoetil). Isolasi plasmid menggunakan kit relatif lebih mudah tetapi mahal jika dilakukan secara rutin (Sambrook dan Russell 2001). Dari metode-metode isolasi di atas, metode lisis alkali merupakan metode isolasi plasmid yang banyak digunakan karena simpel, relatif murah, dan reprodusibilitas (Sambrook dan Russell 2001).

Biasanya plasmid diisolasi dari hasil kultivasi $E$. coli dalam media LB cair yang mengandung antibiotika tetapi $E$. coli dalam LB padat dapat juga digunakan untuk isolasi plasmid. Penggunaan E. coli dalam LB padat lebih menghemat waktu karena tidak memerlukan tahap sentrifugasi untuk mendapatkan sel E. coli dari media cair (Sato et al. 2012).

Masalah utama dalam isolasi plasmid adalah kontaminan yang berasal dari senyawa fenolik dan polisakarida. Polisakarida menghambat aktivitas enzim restriksi Hind III dan Taq polymerase sehingga menyebabkan kesalahan dalam interpretasi data penelitian (Kotchoni et al. 2003). Pengembangan metode isolasi plasmid diperlukan untuk mendapatkan plasmid yang murni, mudah, sederhana, cepat, dan murah. Metode yang digunakan merupakan modifikasi metode lisis alkali dari Kotchoni karena metode ini sederhana dan cepat. Modifikasi metode lisis alkali yang telah dilakukan adalah dengan mengganti diterjen sodium dodesil sulfat (SDS) sebagai senyawa pelisis sel dengan campuran enzim lipase dan diterjen (Yadav et al. 2011).

Tujuan dari penelitian ini adalah mendapatkan metode isolasi plasmid yang mempunyai konsentrasi dan kemurnian tinggi, metode isolasi yang mudah, aman (tidak menggunakan bahan berbahaya), murah, dan waktu yang diperlukan untuk isolasi plasmid antara 50 menit sampai satu jam.

\section{BAHAN DAN METODE}

\section{Bahan}

Luria-Bertani (LB) mengandung ekstrak ragi $5 \%$, tripton $10 \%$, dan $\mathrm{NaCl} 10 \%$ dalam air. LB padat mengandung ekstrak ragi $5 \%$, tripton $10 \%$, dan $\mathrm{NaCl} 10 \%$, agar $2 \%$ dalam air. Larutan I mengandung glukosa $50 \mathrm{mM}$, tris$\mathrm{HCl} \mathrm{pH} 8,025 \mathrm{mM}$, EDTA pH 8,0 $10 \mathrm{mM}$. Larutan I disterilisasi dengan menggunakan autoklaf pada suhu $121^{\circ} \mathrm{C}$ selama 15 menit dan setelah dingin di simpan pada suhu $4^{\circ} \mathrm{C}$. Enzim lisozim ditambahkan ke dalam larutan I saat akan digunakan. Laruran II mengandung $\mathrm{NaOH} 0,2 \mathrm{M}$, SDS 1\% (b/v). Larutan II harus dibuat segar dari stok $\mathrm{NaOH} 2 \mathrm{M}$ dan SDS $10 \% \quad(\mathrm{~b} / \mathrm{v})$. Larutan IIIA mengandung ammonium asetat $8 \mathrm{M}$. Larutan III A disterilisasi dengan menggunakan autoklaf pada suhu $121^{\circ} \mathrm{C}$ selama 15 menit dan setelah dingin di simpan pada suhu ruang. Larutan III B mengandung kalium asetat $5 \mathrm{M}$ $60 \mathrm{~mL}$, asam asetat glasial $11,5 \mathrm{~mL}$, air steril $28,5 \mathrm{~mL}$. Stok larutan enzim lisozim mengandung $20 \mathrm{mg} / \mathrm{mL}$ enzim lisozim dalam tris- $\mathrm{HCl} \mathrm{pH} \mathrm{8,0} 10 \mathrm{mM}$.

\section{Regenerasi E. coli}

Satu koloni $E$. coli yang mengandung plasmid pICZ A diinokulasi dalam media LB padat yang mengandung zeocin $50 \mu \mathrm{g} / \mathrm{mL}$ dan diinkubasi pada suhu $37^{\circ} \mathrm{C}$ selama semalam. 


\section{Isolasi plasmid pICZ A}

Koloni tunggal $E$. coli diinokulasi dalam media LB cair yang mengandung zeocin 50 $\mu \mathrm{g} / \mathrm{mL}$ dan diinkubasi dengan kecepatan putaran $200 \mathrm{rpm}$ dan suhu $37^{\circ} \mathrm{C}$ selama semalam. Sebanyak $2 \mathrm{~mL}$ suspensi $E$. coli disentrifugasi dengan kecepatan $5000 \mathrm{~g}$ selama 5 menit pada suhu ruang. Endapan E. coli diresuspensi dalam $200 \mu \mathrm{L}$ larutan I yang mengandung lisozim $4 \mu \mathrm{g} / \mathrm{mL}$ dan diinkubasi selama 5 menit pada suhu ruang. Kemudian ditambahkan larutan II sebanyak $400 \mu \mathrm{L}$ dan dicampur dengan cara inversi 4 sampai 6 kali. Lalu ditambahkan larutan III A sebanyak $200 \mu \mathrm{L}$ dan dicampur secara hatihati dengan menggunakan mikropipet dan diinkubasi pada suhu $4^{\circ} \mathrm{C}$ selama 5 menit. Suspensi disentrifugasi dengan kecepatan $13000 \mathrm{~g}$ selama 5 menit pada suhu ruang. supernatan dipindahkan ke dalam tabung Eppendorf baru dan ditambah 0,6 volume isopropanol (misalnya jika diperoleh supernatant $1,0 \mathrm{~mL}$ maka ditambahkan isopropanol 0,6 $\mathrm{mL}$ ), dicampur dengan cara inversi sebanyak 4 sampai 6 kali, diinkubasi pada suhu $-20^{\circ} \mathrm{C}$ selama 10 menit, dan disentrifugasi dengan kecepatan $13000 \mathrm{~g}$ selama 5 menit pada suhu $4^{\circ} \mathrm{C}$. supernatan dibuang. Pelet dicuci dengan etanol $70 \%$ $400 \mu \mathrm{L}$ dan disentrifugasi dengan kecepatan $13000 \mathrm{~g}$ selama 5 menit pada suhu $4^{\circ} \mathrm{C}$. Supernatan dibuang dan pelet dikeringkan dengan desikator vakum selama 10 menit. Pelet diresuspensi dalam air bebas DNAse dan RNAse $50 \mu \mathrm{L}$, ditambahkan RNAse A 1 $\mu \mathrm{L}$, dan diinkubasi pada suhu $37^{\circ} \mathrm{C}$ selama 5 menit. Untuk modifikasi metode Kotchoni larutan III A diganti dengan larutan III B.

\section{Konsentrasi dan kemurnian plasmid pICZ A}

Sampel plasmid sebanyak $2 \mu \mathrm{L}$ diukur dengan menggunakan nanodrop untuk mengetahui konsentrasi dan kemurnian plasmid.

\section{Elektroforesis}

Gel agarosa $1 \%$ dibuat dengan mengunakan agarosa $0,4 \mathrm{gr}$ dicampurkan dengan TAE 1X sebanyak $40 \mathrm{~mL}$, dan dipanaskan menggunakan microwave sampai larut, setelah hangat ditambahkan SYBR Safe sebanyak $1 \mu \mathrm{L}$, dicampur sampai homogen, dan dituang ke dalam cetakan dan dibiarkan sampai padat. Sampel sebanyak 5 $\mu \mathrm{L}$ ditambahkan loading dye $6 x \quad 1 \mu \mathrm{L}$ dihomogenkan, lalu dimasukan ke dalam sumur gel agarosa yang terbentuk. Elektroforesis dilakukan pada 100 volt selama 30 menit. Hasil elektroforesis dilihat dengan UV-transilluminator.

\section{HASIL DAN PEMBAHASAN}

Escherichia coli diregenerasi dalam LB padat yang mengandung zeocin $50 \mu \mathrm{g} / \mathrm{mL}$ untuk mendapatkan E. coli yang segar, muda, dan mencegah terjadinya kontaminasi saat penyimpanan. Koloni tunggal $E$. coli digunakan untuk mengisolasi plasmid pICZ A.

Tiga jenis optimasi yang dilakukan pada tahap penambahan larutan III dan kondisi sentrifugasi. Pada metode Kotchoni pengendapan kontaminan atau pengotor plasmid digunakan ammonium asetat $8 \mathrm{M}$ sedangkan pada penelitian ini digunakan larutan yang mengandung kalium asetat $5 \mathrm{M}$ $60 \mathrm{~mL}$, asam asetat glasial $11,5 \mathrm{~mL}$, air steril $28,5 \mathrm{~mL}$ sehingga diharapkan pengotor lebih mudah mengendap. Kondisi sentrifugasi yang dioptimasi pada tahap pemisahan pengotor yang tidak larut dengan plasmid, pada metode Kotchoni disentrifugasi dengan kecepatan putaran $10000 \mathrm{~g}$ selama 3 menit, sedangkan pada penelitian ini disentrifugasi dengan kecepatan putaran $13000 \mathrm{~g}$ selama 5 menit. Hal ini dilakukan agar semua pengotor mengendap sempurna. Optimasi yang ketiga pada tahap pengendapan plasmid, untuk metode Kotchoni plasmid diendapkan dengan penambahan 0,6 volume isopropanol dan diinkubasi pada suhu ruang, sedangkan metode modifikasi plasmid diendapkan dengan penambahan 0,6 volume isopropanol dan diinkubasi pada suhu $-20^{\circ} \mathrm{C}$ selama 10 menit sehingga

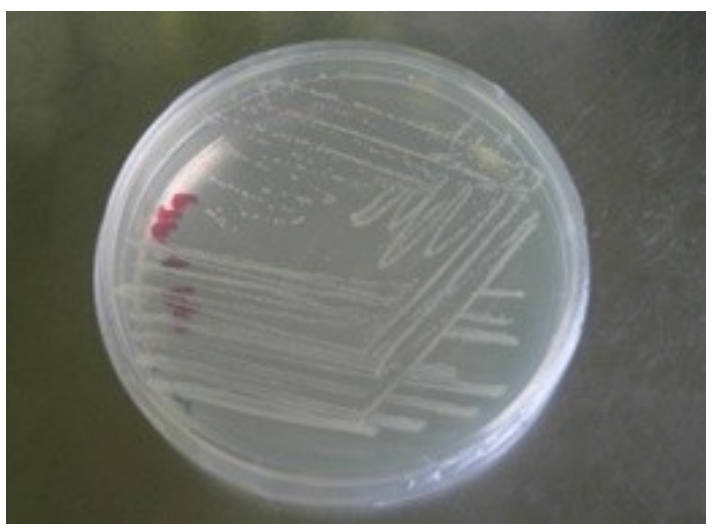

Gambar 3. Regenerasi $E$.coli yang mengandung plasmid 


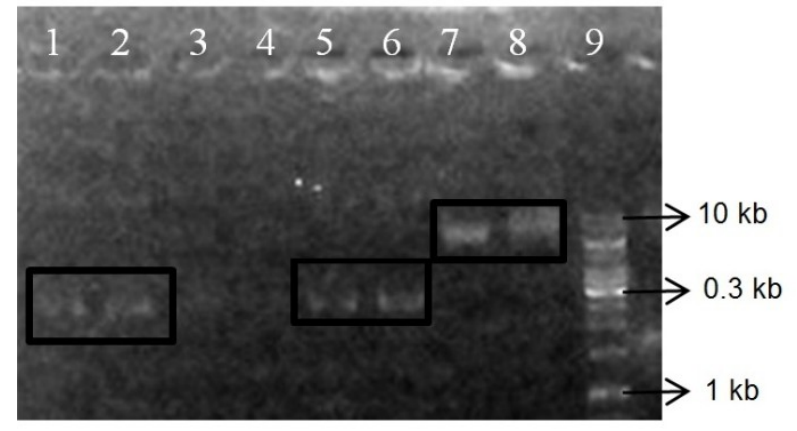

Gambar 4. Elektroforegram plasmid. Sumuran 1-2 hasil isolasi plasmid pICZ A dengan metode Kotchoni, sumuran 5-6 hasil isolasi plasmid pICZ A dengan metode modifikasi, sumuran 7-8 hasil isolasi plasmid pET-21d(+) dengan kit, Marker $1 \mathrm{~kb}$.

diharapkan jumlah plasmid yang mengendap lebih banyak karena suhu dingin akan menyebabkan berkurangnya kelarutan plasmid.

Salah satu faktor keberhasilan proses kloning adalah konsentrasi dan kemurnian plasmid yang diperoleh dari hasil isolasi. Penentuan konsentrasi plasmid diukur pada panjang gelombang $260 \mathrm{~nm}$ sedangkan kemurnian plasmid ditentukan dengan membandingkan serapan pada panjang gelombang 260/280 nm. DNA murni mempunyai nilai antara 1,8 sampai 2,0 . Untuk penentuan konsentrasi dan kemurnian plasmid pICZ A digunakan Nanodrop. Dari hasil penentuan konsentrasi plasmid pICZ A diperoleh antara 3,3 sampai $3,8 \mu \mathrm{g} / \mu \mathrm{L}$, sedangkan metode Kotchoni menghasikan plasmid sebanyak 2,0 sampai $2,8 \mu \mathrm{g} / \mu \mathrm{L}$. Kemurnian plasmid pICZA adalah 1,99 (memenuhi persyaratan). Modifikasi metode Kotchoni menghasilkan jumlah plasmid lebih banyak dibandingkan metode Kotchoni.

Hasil visualisasi plasmid plCZ A menunjukkan bahwa plasmid yang diperoleh dengan modifikasi metode Kotchoni mempunyai pita yang lebih tebal dibandingkan dengan metode Kotchoni (Gambar 4.) Modifikasi Kotchoni mempunyai lebih tebal karena mempunyai konsentrasi plasmid lebih besar (antara 3,3 sampai 3,8 $\mu \mathrm{g} / \mu \mathrm{L})$.

\section{KESIMPULAN}

Modifikasi metode Kotchoni menghasilkan plasmid pICZ A antara 3,3 sampai 3,8 $\mu \mathrm{g} / \mu \mathrm{L}$ dan kemurniannya 1,99.

\section{DAFTAR PUSTAKA}

Birnboim HC, Doli J (1979) A rapid alkaline extraction procedure for screening recombinant plasmid DNA. Nucleic Acids Res 7:1513-1523

Brown TA (2010) Gene Cloning and DNA Analysis: An Introduction, ed. Ke-6. Graphicraft Limited. Hongkong.13-17

Dederich DA, Okwuonu G, Garner T, Denn A, Sutton $A$, Escotto $M$, Martindale $A$, Delgado O, Muzny DM, Gibbs RA, Metzker ML (2002) Glass bead purification of plasmid template DNA for high throughput sequencing of mam-malian genomes. Nucleic Acids Res 30:1-5

Easyselect Pichia Expression Kit for Expression of Recombinant Protein Using pPICZ and pPICZa in Pichia https://tools.thermofisher.com/content/sf s/manuals/easyselect_man.pdf, diakses 20 Oktober 2015

Kiran C, Sreekanth P, Ponnala D, Paithankar KR (2010) A quick and economical method to isolate plasmid DNA for large scale sequencing. Int J Appl Biol Technol 1:1236-1238

Kotchoni SO, Gachomo EW, Betiku E, Shonukan OO (2003) A home made kit for plasmid DNA mini-preparation. Afr $\mathrm{J}$ Biotechnol 2:88-90

Palomares LA, Mondaca ST, Ramirez OT (2004) Production of recombinant proteins: challenges and solutions. In: Methods in Molecular Biology: Recombinant Gene Expression Reviews and Protocols, vol 267. Balbas P \& A Lorence (ed). Humana Press Inc., New Jersey

Perez-Ortin JE, Ramon D, Ferrer S, Tordera V (1986) Rapid plasmid isolation, A laboratory experiment. Biochem Edu 14:142-144

Sambrook J, Russell DW (2001) Molecular Cloning, vol. 1.Cold Spring Harbor Laboratory Press., New York

Sato M, Akasaka E, Saitoh I, Ohtsuka M, Nakamura S, Sukarai T, Watanabe S (2012) A simplified protocol for the semilarge scale recovery of plasmids from Escherichia coli grown on agar plates. J Biomed Sci Eng 5:406-408

Yadav P, Yadav A, Garg V, Datta TK, Goswami SL, De S (2011) A novel method of plasmid isolation using laundry detergent. Indi J Exp Biol 49:558-560 